DOI: $10.31866 / 2410-1915.21 .2020 .208265$

UDC 061.2:82.02+7.03](477.83-25)"192"

\title{
PRESENTATION ACTIVITIES OF THE LVIV LITERARY AND ART ASSOCIATIONS AT THE BEGINNING OF THE 1920s
}

\section{Liliia Syrota}

PhD in Philological Sciences, Associate Professor, ORCID: 0000-0001-7237-291X, liljasyrota@yahoo.com, Ivan Franko National University of Lviv, 1, Universytetska St., Lviv, 79000, Ukraine

\section{For citations:}

Syrota, L. (2020). Presentation Activities of the Lviv Literary and Art Associations at the Beginning of the 1920s. Culture and Arts in the Modern World, 21, 264-280. https://doi.org/10.31866/24101915.21.2020.208265.

The purpose of the article is to reveal the peculiarities of the presentation activities of the Ukrainian centres of Lviv in the early 1920s, to promote understanding of the Ukrainian cultural life of this city. Periodical publications of that period were used for the analysis. The defining methodological principle of this study has been the principle of historicism, which allowed us to determine the meaning, place and consequences of the presentation activities as a new form of communication of creative associations. A systematic approach made it possible to determine the interaction of creative groups in Galicia in the 1920s, and methods of analysis and synthesis were used to study the creation of conditions for effective communication with the audience in order to restore cultural life. The scientific novelty of the article lies in the fact that specific literary and artistic events and their significance for successful creative activity have been comprehensively studied. The presentation activities became possible due to the constant demand for creative innovations, which had been increasing in Galicia since the National Liberation Competitions.

Conclusions. It has been demonstrated that the presentation activity in the $1920 \mathrm{~s}$ became a new and for that time sensational form of communication with the supporters of the creative associations, and was aimed at the recovery of the cultural life of Galicia. At the same time, the presentations mostly corresponded to the social and cultural requirements and brought great success to their organizers because they receive extended reviews in the press, as well as due to the ability of the "Mytusa" group to concentrate around themselves not only the Ukrainian literary forces of Galicia, but also emigration formed in Poland, Czecho-Slovakia, Germany, Austria in the 1920s. It has been shown that the initiators of cultural events - the groups "Mytusa" and "Bohemia", the authors of the magazine "Budiak" - managed to maintain connections by gaining the support of others, instilling their thoughts and forms of behaviour and to offer to the public the avant-garde ideology and world view through the imposition on the supporters the desired ideas and behaviour during the literary events and through their own adherence to these ideas. Thus, creative presentation occupies a prominent place in modern art. Thanks to it, the mass movement

(C) Liliia Syrota, 2020

The article was received by the editorial office: 02.03 .2020 
for "new ways", which developed in the interwar period, was directed to the traditions and realities of the Ukrainian life.

Keywords: presentation; the 1920s; Galicia; Lviv; creative search; literary group "Mytusa"; magazine "Budiak"; literary and art society "Bohemia”; idea; world view; sociocultural requirements.

\section{Introduction}

Socio-cultural practices of art institutions and associations, regardless of the time, place and number of its participants, as a rule, tend to focus on the world as a complex system that combines various actions of an individual and a group. Therefore, any organization (regardless of its scale) that claims to maintain its independent existence, builds clear and simple relationships in the socio-cultural space.

One of the forms of organizing the communication between art institutions in order to promote the creative work is the presentation, which, due to its effectiveness, becomes increasingly important and relevant in modern society. However, in the first decades of the twentieth century, the way the results of creative work were presented to the audience got so progressive that it provided a guaranteed success. It was a presentation as a new form of communication that mostly corresponded to social and cultural requirements and was used in the 1920 s by representatives of literary and artistic associations of Galicia. It became effective in a creative communication, and made more active the Lviv's cultural life after the First World War and became popular not only in Galicia, but also in Dnieper Ukraine.

At the same time, many important facts, which point to the increased creative activity in Galicia in the 1920s, have not been sufficiently studied yet and introduced into a wide scientific circulation, which determines the relevance of the topic of the article.

The literary and artistic life of the Ukrainian intelligentsia of the first postwar years has repeatedly been the focus of attention of researchers of Ukrainian modernism and avant-garde, who analysed certain aspects of the activities literary, publishing, journalistic - of such creative associations as "Mytusa", "Budiak", "Bohemia".

In particular, L. Snitsarchuk (2009), considering the regularities of the formation of the Ukrainian information space in Galicia, calculated that 779 periodicals were published. At the same time, "one-third of which were characterized by irregularity and short duration of publication and, significantly, the "laxity" of the content, which is primarily associated with the inherent for Ukrainians eternal search for values, spirituality, high truths" (p. 27). Despite this, the author noted the increasing number of the Ukrainian print media, which is connected with the ability of the Ukrainian creative workers to mobilize and conduct an important national business in extremely unfavourable conditions, adapt to censorship requirements and respond quickly (p. 50). The researcher has also studied the formation, development and functioning of the Ukrainian satirical and humorous press of Galicia during the interwar period (Snitsarchuk, 2001). 
Studying the literary group "Mytusa”, T. Salyha (1997) in his work "Imperative" claimed that the Ukrainian publishing products with dozens of original and translated books of local authors and authors from Dnieper Ukraine played an important role in the literary life of Ukraine, and "cultural and art centres have awakened national consciousness in Galicia” (p. 99), and the literary group "Mytusa" creatively legitimized symbolism and contributed to all-Ukrainian surge of a new wave of symbolism (p. 107).

L. Syrota (1998) in her research examines the creative work and significance of the "Mytusa" group in the Western Ukrainian literary process of the 1920s, emphasizing that the "Mytusa" poets were looking for forms that could force the reality of that time.

I. Prokopchuk (2010), studying the avant-garde art of the 1920s - early 1930s, argued that Ukrainian periodicals did not stand aside from the issues of the avant-garde development, new architecture, actively participating in the Pan-European process. At the same time, Ukrainian artists through the print media had the opportunity to get acquainted with and critically comprehend the rational, positive and negative aspects of the concepts of the art of that period, as well as the works of leading domestic and foreign artists (p. 24).

Ukrainian-Polish relations of the first post-war years were studied by Yu. Savchyn (2014), who on the basis of various genre publications of the magazine "Budiak", highlighted the most relevant aspects of the relationship between Ukrainians and Poles who found themselves in the status of warring parties. At the same time, the author emphasizes that "using satire and humour, the authors strongly criticized, and sometimes ridiculed, condemned the realities of social and political life, the state policy of Poland towards Ukrainians" (p. 43).

However, unfortunately, there are not enough all-embracing studies in which these associations would be the subject of a comprehensive detailed analysis and would be introduced into the Ukrainian cultural context.

\section{Purpose of the article}

The purpose of the article is to reveal the peculiarities of the presentation activities of the Ukrainian centres of Lviv in the early 1920s, to promote understanding of the Ukrainian cultural life of this city. Periodical publications of that period were used for the analysis.

The defining methodological principle of this study has been the principle of historicism, which allowed us to determine the meaning, place and consequences of the presentation activities as a new form of communication of creative associations. A systematic approach made it possible to determine the interaction of creative groups in Galicia in the 1920s, and methods of analysis and synthesis were used to study the creation of conditions for effective communication with the audience in order to restore cultural life.

The scientific novelty of the article lies in the fact that specific literary and artistic events and their significance for successful creative activity have been comprehensively studied. The presentation activities became possible due to 
the constant demand for creative innovations, which had been increasing in Galicia since the National Liberation Competitions.

\section{Main research material}

Subjects of the sociocultural space have often been used and continue to use various communication tools to promote their activities. An important aspect of this process is the ability to present your creative product in a high-quality way and communicate it to the public in time by means of media or by your own efforts. The practice of introducing subjects to each other is called presentation.

According to the Ukrainian researchers, there is no generally accepted definition of the concept of presentation. Yu. Polikarpova (2012) noted that "in the works of foreign experts, it is used mainly to indicate a message containing a new idea, its explanations, fresh information, demonstrates material for further discussion and perception” (p. 159). Ukrainian researchers O. Tarnopolskyi and Yu. Avsiukevych offer the most complete definition: "presentation - a professionally prepared monologue statement, combined with a specific task and situational conditions, which is based on the results of analytical research of a particular problem, has a clear logical and compositional design and is aimed at effectively informing, motivating or persuading a certain audience, taking into account its main cultural and socio-demographic characteristics" (Tarnopolskyi \& Avsiukevych, 2007). In other words, a presentation is not only the disclosure of certain information in an interactive form, but also an effective dialogue with the audience, a way of presenting the material, influencing the audience and getting feedback.

Using the technology of presentation, a creative person presents to the other side an actual and innovative idea as a "part of himself" - his skills, intellectual abilities, product with the prospect of their further development. Thus, it assigns the role of action to the presentation activity, which opens and establishes contact with the viewer or reader, which is necessary for a person to influence the external environment or to interact with it.

If it is impossible to imagine the members of the modern society without the presentational competence, then in the first decades of the twentieth century, presentations of the results of creative work to the audience, public personal communication with readers, creative responsibility for the results works, slogans - were so innovative and sensational that they provided $100 \%$ success to their organizers. Young representatives of literary and artistic associations, due to their ability to work in a team, successfully build relationships with other people, attract recognized authorities within the field of literature, art or politics, effectively communicate with their environment not only in a written form (publication of a printed periodical, collections), but also orally, choosing an adequate method of creative communication in accordance with the sociocultural requirements of the 1920s in Galicia. Let's take a closer look at the types of personal and collective presentation activities of that time.

The most well-known creative association of Lviv in the early 1920s was a literary group "Mytusa”. Its representatives held several high-profile liter- 
ary and artistic meetings, which received good press coverage. In particular, on November 27, 1921, the first meeting of Lviv poets with the public took place on the stage of the theatre "Ukrayinska Besida" ("Zi studentskoho zhyttia. Halychyna", 1922; "Lviv. Vechir Molodoho Mystetstva", 1921). The purpose of this gathering was to renew the modernist search in Galicia. The intention of Lviv poets was realized through the introduction of the ideas of the Kyiv group "Muzahet", whose supporters they were, and of their own works to the audience. Thus, it was visually (by personal performances) demonstrated not only the vitality of modernistic ideas in Galicia, but also the emphasis on the prospects of this direction. In addition to Vasyl Bobynskyi, Oles Babii, Roman Kupchynskyi, Yurii Shkrumeliak from "Mytusa" group, Roman Holiian, Stepan Charnetskyi, Halyna Orlivna, Antin Pavliuk, Klym Polishchuk, Mykhailo Serdytskyi, Lev Lepkyi ("Zi studentskoho zhyttia", 1921) were also involved in the organization of the event.

The presentation began with opening remarks by Klym Polishchuk, in which he noted the formation of the qualitatively new trends in the art. In his opinion, futurism was a striking manifestation of the "young art" of the 1920s. Having named the representative of futurism in Galicia - Lev Lepkyi - and also focused attention on the innovative work of V. Bobynskyi, O. Babii and R. Kupchynskyi, K. Polishchuk pointed out another feature of the avant-garde of that time - "a competition to return to the primitive." His discourse on Ukrainian modern art was accompanied by criticism of the development of pre-war modernism. The sharp statements by K. Polishchuk reporter of the magazine "Ways of art" conveyed as follows: “...attacked the pre-war luminaries of our young poetry: Oles, Chuprynka - the stars have already extinguished against the descending sun of futurism" ("Lviv. Vechir Molodoho Mystetstva", 1921, p. 146). K. Polishchuk's criticizing attitude to the previous literary works, the growing role of futurism in the national culture significantly revealed the desire of "Mytusa" group for ideological and stylistic changes.

Having seen the approval of K. Polishchuk's views by those who attended the event, its organizers made no changes into pre-arranged programme of the evening. The purpose of this meeting was to introduce the innovative work of the Kyiv group "Muzahet" and young Lviv writers who wanted to further develop the experiments of Kyiv group. The idea of the exhaustion of the modernistic line of O. Oles, M. Voronyi and H. Chuprynka and other famous authors and the need for further development of symbolism V. Bobynskyi, R. Kupchynskyi, A. Voloshchak tried to confirm by reciting the works of the Dnieper writers P. Tychyna, V. Yaroshenko, O. Slisarenko, Ya. Savchenko, M. Semenko, A. Pavliuk (Doroshenko, 1962, p. 315). The young and promising poet Mykhailo Serdytskyi also spoke at the event. ("Lviv. Vechir Molodoho Mystetstva", 1921, p. 147). He read the poems "Mother and child", "Thoughts fly like a swift swallow", "Rifle body", which were included in his military collection of poems. R. Holiian, S. Charnetskyi and M. Voronyi also communicated with the audience at this event. The first part of the literary evening includes: K. Polishchuk's speech, the reading of poems by writers from Dnieper Ukraine and emigrant poets who did not associate themselves with the group "Mytusa". 
In the second part of the evening, the representatives of the literary group "Mytusa" recited their works. V. Bobynskyi, whose poems came as a surprise to the listeners, was the first to inform about the literary group. In the magazine "Postup" we find the following assessment of his poems: “... the headlines and the opening lines with very original comparisons and perfectly developed form immediately attracted all the attention of listeners" ("Lviv. Vechir Molodoho Mystetstva", 1921, p. 146). The poet read the poems "Silver poplars" "Kamo?", "My sadness" from the collection "My sadness", which was to be published at the turn of 1921-1922 ("Zi studentskoho zhyttia", 1922, p. 53).

Oles Babii, at that time known as a feuilletonist of the newspaper "Dilo", continued the evening's programme with his poems "Youth, don't leave me", "The enemy army is coming" (another name for this poetry is "The enemy is coming”), "Hosanna”. Blind poet Andrii (Antin) Voloshchak, Mykhailo Serdytskyi, Halyna Orlivna, Klym Polishchuk complemented the performances of the group "Mytusa" by reading their own poetry and prose works. The author of the article in the magazine "Postup" did not mention which of their poems they had read. R. Kupchynskyi and Yu. Shkrumeliak ended the presentation programme by reading several new poems. Yu. Shkrumeliak read poetry from the collection "Cosmic depth", "Sonnet to the moon", "Storm", "Sunset", and R. Kupchynskyi presented his own collection of poems "Village", reciting several poems from it miniature sketches "Heat", "Wind", "Bad weather", "The Indian summer”, etc.

According to the magazines of that time - "Postup" (Lviv) and "Shliakhy Mystetstva" (Kharkiv) - the evening was a success ("Lviv. Vechir Molodoho Mystetstva", 1921, p. 147). Positive reviews in periodicals showed the significant public interest in the stylistic and philosophical search of Galician writers and writers from Dnieper Ukraine. In particular, this interest is evidenced by the fact that the First Evening of Young Art, as this meeting was called, gathered a significant number of the Ukrainian intellectuals of Lviv and thus, proved the existence of the appropriate conditions for the deployment of the active presentation activities by creative associations. The essence of the ideological and artistic position of the participants of "Mytusa" group was not to follow the examples of famous authors, draw inspiration from artistic experiments, which are understood as a support of freedom of creative search.

At the end of 1921, there were a few more literary presentations that did not receive extended reviews, since they were all similar in programme. References to these events are found in the reviews of the magazine "Mytusa" by M. Voronyi, B. Lepkyi and L. Biletskyi (Biletskyi, 1922; Voronyi, 1922). In particular, M. Voronyi (1922) wrote: "This aesthetic and artistic phenomenon itself, by the fact of its appearance, has a special value and weight for the arbiters of elegance" (p. 2). This comment - an appreciation of the activities of "Mytusa" - showed that all presentations were successful due to the existing demand, or need, for innovative creativity, and were a successful organizational step to maintain a long-term interest in the literary group.

In 1922 the presentation activity of the "Mytusa" was expanded. In addition to recitations, they present their ideological and artistic experiments in the form of performance. In particular, on March 26, 1922, a "Spring evening" was 
organised in Lviv for the disabled Sich Riflemen, which was attended by writers V. Bobynskyi, R. Kupchynskyi, O. Babii, L. Lepkyi, graphic artist P. Kovzhun, actors of the Lviv theatre "Ukrayinska Besida", public figures ("Pershyi "Vesnianyi vechir", 1922). The programme of this event brought together artists from different fields of art and its various directions. In addition to V. Bobynskyi, R. Kupchynskyi, O. Babii, who developed symbolism, L. Lepkyi - a representative of Galician futurism - spoke to the public. At the gathering, he presented his one act farce "Le-Le in spring-early spring, or the Birthday of the Futurist" ("Pershyi "Vesnianyi vechir", 1922). The scenery for the works of V. Bobynskyi, R. Kupchynskyi, O. Babii and for the L. Lepkyi's play was made by P. Kovzhun. As Ye. Malaniuk wrote, "Kovzhun - is now a fashionable tailor for poets" (Malaniuk, 1923). Designing the collections of poems of the "Mytusa" representatives for public creative presentations, and "Mytusa" magazine, P. Kovzhun, using national imagery in the innovative way, by means of posters, graphics, fancy decorations emphasized the ideological and aesthetic orientation of the meetings with the admirers of their work, and meaningful particularity of their print editions.

On April 1, 1922, on the stage of the Lviv theatre "Ukrayinska Besida", young poets organised another presentation - "Evening of a Song and a Word" ("Novynky", 1922). V. Bobynskyi and O. Babii, representatives of the "Mytusa" group, also took part in the event. And though it was not possible to find out who else participated in the evening, what was its programme, the attention of the reporter of the Galician newspaper "Hromadskyi Vistnyk" to these two figures is a proof of high appreciation of their work.

During 1921-1922, the famous symbolist writer Mykola Voronyi often visited Lviv (Lysty M. Voronoho do I. Kalynovycha, 1921-1922). On March 28, 1922, $\mathrm{V}$. Bobynskyi and $\mathrm{O}$. Babii arranged a concert and a literary evening on the occasion of the 50th anniversary of the poet and the 25th anniversary of his creative activity (Opovistky, 1922). Mykola Voronyi, who was at that time in Volyn region, was invited to the event. Songs based on the lyrics of the famous poet and his poetic works were performed.

In May 1922, the "Mytusa" group organised another presentation "Evening of Poetry", which became the last for them (Biletskyi, 1922). This was an event attended by the most active representatives of "Mytusa" - V. Bobynskyi, R. Kupchynskyi, O. Babii, Yu. Shkrumeliak, L. Lepkyi. Each of them read new works at the meeting. V. Bobynskyi - poems "Hornet" and "Farewell", R. Kupchynskyi - poetry "Fable”, O. Babii - "Quieter' and "Prayer of the Strong”, Yu. Shkrumeliak - satires, and L. Lepkyi presented his new jokey play "Child of Spring”. P. Kovzhun again was the author of the scenery at this literary and artistic presentation. Mykola Voronyi also participated in the presentation, he read his poems "Invincible Force" and "A Fly".

Leonid Biletskyi, at that time well-known literary critic-emigrant, positively commented on the works read by the representatives of the "Mytusa" group. He was the first to notice the public's indifference as to their creative search, and he wrote about this in his review. His conclusion was made on the basis of a small number of spectators in the hall. If at the beginning of the movement for 
"new ways" in literature and art (autumn of 1921), there were many supporters of avant-garde search (remember the "Evening of Young Art" and the variety of names in the magazine "Mytusa"), then over time, the interest in them waned, because the audience did not get in a full measure of what the poets constantly declared throughout the autumn and spring of 1921 and 1922: "from symbolism - to new ways". In particular, they spoke a lot about the innovation of Muzaget search of P. Tychyna; attention was focused on the importance of rethinking of national traditions, the idea of further development of symbolism up to the creation of a qualitatively new literary and artistic direction was proclaimed; futurism, which became one of the declared "new ways", the idea of primitivism as a step towards avant-garde were glorified. Most of the theses were poorly confirmed in practice.

In general, the literary group "Mytusa" combined a variety of creative practices which did not contradict to the common goal - "on new ways'. The group's mutual ideological and aesthetic platform contributed to the realisation of the goal: to create, as P. Tychyna did, a new example of the use of national imagery and rhythmics, a new synthesis of traditions and avant-garde trends, and to approve the idea of a continuous return of an artist to folk sources, to which everyone had their own way. S. Yefremov (1995) wrote about P. Tychyna as of a new reference point for the Ukrainian intelligentsia of Galicia in the 1920s: "the creativity of P. Tychyna put a certain line in our writing... the writers had to rebuild their lyre in accordance with the tone set by P. Tychyna" (p. 625).

Another reason for the success of presentations was that the literary group "Mytusa" managed to concentrate around themselves not only the Ukrainian literary forces of Galicia, but also emigration, which was formed in Poland, Czecho-Slovakia, Germany, Austria in the 1920s. Galicians M. Matiiv-Melnyk, V. Sofroniv-Levytskyi, Ye. Yavorovskyi, A. Voloshchak, M. Serdytskyi, R. Holiian, S. Charnetskyi, L. Lepkyi grouped around "Mytusa", took an active part in its events and were published in its magazine. Mykhailo Ostroverkha from Podillia region did not mind joining "Mytusa". He got interested in the Lviv group, which he described as "sparkled", "made avant-garde steps in literature" (Ostroverkha, 1957, p. 59). K. Polishchuk, A. Pavliuk, H. Orlivna, F. Dudko, P. Kovzhun were the backbone of emigrants of "Mytusa" group. They participated in the presentations, and their works were published in the group's magazine.

In the early 1920s, when cultural life was just being revived after the liberation competitions, this group and its magazine became almost the only platform for demonstrations of artistic and aesthetic ideas and poetic experiments of young artists. Lviv's wide publishing opportunities, interests and support of the public attracted them. "Mytusa”, with its activity, publicity and numerous supporters, directed public sentiments, national pathos to the new figurative and strophic experiments, understanding of the aesthetics of the past as a real novelty, inseparable from traditions, the approval of the national identity of modern literature and art.

The "Mytusa" group was focused on the idea of a single Ukrainian modern space, unity of the artistic process and its completeness, its individualization on the national basis. It presented an artistic concept that allowed artists with 
different world views to coexist. Their performances demonstrated the value of art works in close connection with the public. Therefore, meetings were organised with unprecedented speed. Their regularity and emphasis on active interaction with the audience helped to overcome pessimism and world view stereotypes.

It was a presentation as a new form of communication with supporters and visualization of search that accelerated interest in Lviv search and added resonance to their events. Thanks to the wide public presentation activities, "Mytusa" managed to activate the Lviv post-war cultural life, became popular not only in Galicia, but also in the Dnieper Ukraine and in the emigration. This is illustrated by the reviews even in the Kharkiv press, as well as by the authorship of reviews - these were well-known critics and poets from Lviv and emigration.

The performances of those who grouped around the printing organ of Galician futurism - the magazine "Budiak" were also popular. Their events were another attempt to actualize the ideas of avant-garde in the public discourse of Galicia in the early 1920s. Participants of the literary events organised by the editorial board considered their activity as an act for the dissemination of futuristic experiments into the masses, and were always open to wide representation and discussion ("Vechir plachu Budiaka", 1922; "I-yi chainyi vechir Budiaka", 1921). The announcement of one of such literary gathering stated that on Sunday, January 15, in the cafe "Republika", the magazine "Budiak" arranges a Big Malanka night of "merry" futurists ("Velykyi Po-Malanchyn Vechir Smikhu", 1922). And here is the text of another announcement: "On the general claim of our citizenship, the editorial board of the satirical and humorous magazine "Budiak" organises the second Big Malanka Night of Laughter on Sunday, January 22, 1922, in the hall of "Republika". Apart from the announcement, there were a lot of interesting additions. The victory of futurism. "Express" collects showers of applause. In the interpretation of the latest futurist.[ic] music composition: "The Cry of the Stomach". (Only for people with a lot of nerve). Admission by invitation only..." ("Na zahalne domahannia", 1922). On March 12, 1922, on the First "Crying Night", "in the paroxysm of melancholy as black as the African night "Love of goat and grandmother" participated musicians (bandura players), futurist poets, humorists ("Vechir plachu", 1922). As we can see, the organizers of these musical and theatrical presentations were not afraid to bring their provocative and scandalous works to the stage and turned the evenings of poetry and art into bright staged events. The number of events as well as the number of spectators was a proof of success. It is known that these events were attended by famous artists, including actors M. Krushelnytskyi and P. Davydovych ("Pozir!", 1922, "Chainyi vechir", 1922).

In contrast to the group "Mytusa", "Budiak" created a lot of poetic manifestos, which demonstrated their unity, agreement of opinion, purposefulness for innovation. In particular, they wrote about "our friendship in our circle, ... brotherhood, ... love, ... each of us is ready for anything" ("Tost", 1921), at the gatherings they made accent on the goal of creativity: "modern troubadour is coming, // Let everything banal perish!..” (Tarnohradskyi, 1921), on the new emotions and the participants: "There is an emotion, there are new people - well, the 
nerves calm down" (Shvung, 1921), focused on laughter and condemned pessimism: "and for the sad bad time // we carry laughter, hearty laughter!" ("Nashe viruiu", 1921). "Hearty laughter", "sincere humor that light singing will carry, // at least for a short time - for a minute // forget the troubles of our days!" ("Spivomovkam", 1921) were considered as a manifestation of creative work, which is not limited by any boundaries. In the L. Lepkyi's poem "Ditty" it is noted about "hearty laughter", "sincere humour" as "a sound of freedom" ("Spivomovkam", 1921). In another L. Lepkyi's poem "In honour of Mykola Voronyi (on the occasion of the 50th anniversary)", it is said about another idea that united the group: "a strong spirit of rank', which will bring freedom (Lepkyi, 1922). Not less important for the understanding of the ideological and aesthetic unity of the authors of the magazine "Budiak" - L. Lepkyi, K. Polishchuk, R. Kupchynskyi, D. Krenzhalovskyi, R. Teodorovych, R. Holiian, S. Romanivna and others - and the theme of their presentations was the idea that a man with all his advantages and disadvantages should arouse the interest of the artist, and this full comprehension of a man is revealed at best in Budiak's numerous anecdotes and humorous writings read out at the gathering-presentations.

The active artistic and social position of the authors of the "Budiak" magazine (they are also regular participants of the events) radically changed the literary and artistic environment of Lviv after the war. The general public welcomed the futurists immediately, since they attracted the interest of the people with new artistic and aesthetic values, bringing the creativity closer to social problems. Appeal to the genres of smile and anecdotes, creating new and parodying old genres of the $19^{\text {th }}$ century helped to overcome the influence of authoritative writers.

Organizational activities, high verbal activity of the literary and artistic community, and the fact that the majority of participants had a formed attitude to the avant-garde and experiments as a necessary condition for the development of the Ukrainian culture led to the improvement of the presentation practice. We believe that the revival of the cultural sphere (an increase in the number of original works, organizational changes in the process of communication with the public, the arrival of a new generation of gifted artists, etc.) in the best way indicated the spiritual recovery in the post-war Galicia.

Despite the organizational, ideological, aesthetic and stylistic innovations, success with the public, the critics negatively evaluated the literary gatherings of "Budiak". In particular, its participants were unfairly accused of lack of taste, meaninglessness, their one-act plays were equated with street humour, cynical satire, and it was generally noted that the creative work of futurists is "unhealthy symptom", "moral rot" ("Vesnianyi "vechir plachu", 1922).

In the early 1920s, presentations of the Lviv society "Bohemia" were also influential. They were conducted by the artists who had an experience in the organization of the public performances - R. Kupchynskyi, O. Babii, L. Lepkyi, M. Holubets, I. Rudnytskyi, P. Kovzhun, as well as the famous literary critic M. Rudnytskyi, who informatively, briefly and reasonably presented new results of the avant-garde search of little-known Ukrainian poets, satirists, actors and musicians of Galicia ("Bohema", 1923). In addition, the literary and artistic so- 
ciety "Bohemia" acquainted the general public with the latest achievements of the European modernism, developed cultural cooperation through the joint art projects. "The idea of all-Ukrainian activism", which O. Babii proclaimed at the Evening with B. Lepkyi's event in 1923 (Kedryn, 1923) revealed not only the creative position of "Bohemia", but also the spiritual hopes of that time in general. Like the "Mytusa" group, "Bohemia" felt "nostalgia for the patent on "a real, recognized poet” (Bobynskyi, 1990, p. 451). Bohdan Lepkyi became such a poet. The night of author's poetry can also be considered a presentation of a creative work, since, in addition to the organizers and guests who read out the poems of B. Lepkyi, the writer himself, to whom this meeting was dedicated, attended the gathering ("Vechir, posviachenyi tvorchosti Bohdana Lepkoho", 1923).

The new group, like the literary group "Mytusa", did not narrow the search by the manifestation of a certain world view or imagery. Nor did it limit the aesthetic search to a futuristic experiment on the edge of literature and other art forms. For the group, it was important to increase the participation of talented young people and representatives of the older generation in the cultural life. Society "Bohemia" publicly revealed its path of ideological and stylistic evolution - from Mytusa's return to national origins and to the creation of a new bohemian, elite literature that stood above the reality. They, like their predecessors, through public presentations, managed to attract and gather many people around them in a short time - representatives of art, science, education, and politics.

The themes of the literary presentations of 1923 - "Malanka's Evening” (January, 17) ("Malanchyn Vechir u Lvovi", 1923), "Bohemia Night” (January, 22) (Zhontik, 1923), "Masquerade Ball "Bohemia” (February, 10) (Chmelyk, 1923), "A night of Bohdan Lepkyi" (March, 3) - were different, but the method of their preparation and carrying out was almost identical. A creative group of initiative active participants was identified, their task was to develop a scenario, provide announcements, make an invitation, arrange a room, invite guests, etc. The first condition for the success of their work is - the novelty, brightness and credibility of information, including the names of the events. The desired result (full house) was achieved by various methods: emotional appeals of moderators, staging of fragments of artistic works, recitation of poems and prose passages, guest performances, masquerade costumes of participants, inspection of the scenery.

With the help of purposeful and rational events for the representatives of various spheres of art, the promotional activities of "Bohemia" became even larger in organization, more universal in terms of the number of participants, more optimistic, and did not lose its leadership features in the cultural life of Galicia. Musician M. Haivoronskyi, actors V. Durdykivna, R. Kryshtalskyi and P. Pshenychka, singers M. Svirska, S. Fedortsivna, politicians V. Doroshenko, D. Dontsov, scientists I. Krypiakevych, V. Shchurat, M. Korduba, artists P. Kovzhun, P. Kholodnyi, R. Lisovskyi, Yu. Mahalevskyi, L. Perfetskyi, sculptor O. Arkhypenko, etc. took part in the events ("Maskarad "Bohemy", 1923).

It should be noted that not all literary associations of that time organised presentations of their own search. For example, the literary and artistic society "Sontsetsvit" (Tarniv, 1921-1922), to which belonged M. Obidnyi, Yu. Lypa, 
Ye. Ivanenko, M. Kovalskyi, B. Lysianskyi, N. Livytska, P. Tenianko, held a literary evening dedicated to the work of A. Dante, the work of M. Voronyi (both in the spring of 1922), published two collections - the almanac "Sontsetsvit" and a collection about A. Dante, which demonstrated their organizational unity, less appeal to the national themes and images, the understanding of their meaning for the contemporaries (V.P, 1921).

\section{Conclusions}

Thus, the presentation activity as a new form of communication with the supporters of the creative associations in the 1920s was aimed at the recovery of the cultural life of Galicia and emigration and accelerated the interest in Lviv search. The most famous creative associations of Lviv were: the literary group "Mytusa", artists, who were grouped around the publication of Galician futurism - the magazine "Budiak", and the Lviv society "Bohemia". At the same time, the appeal of "Mytusa" to search for the new ways caused a continuous chain reaction: every year new literary associations appeared, albeit short-lived, but extremely active and numerous by the number of participants. They consolidated the fragmented literary and artistic forces with the help of: print organ (magazines "Mytusa" and "Budiak"), an innovative creative position and even literary event-presentations demonstrated the general retreat from realism towards an innovative view of the world and art.

It has been proved that presentations as a new and for that time sensational form of communication mostly corresponded to the social and cultural requirements and brought great success to their organizers because they receive extended reviews in the press, as well as due to the ability of the "Mytusa" group to concentrate around themselves not only the Ukrainian literary forces of Galicia, but also emigration formed in Poland, Czecho-Slovakia, Germany, Austria in the 1920s.

The initiators of cultural events - the groups "Mytusa" and "Bohemia", the authors of the magazine "Budiak" - managed to maintain connections by gaining the support of others, instilling their thoughts and forms of behaviour and to offer to the public the avant-garde ideology and world view through the imposition on the supporters the desired ideas and behaviour during the literary events and through their own adherence to these ideas.

Thus, creative presentation occupies a prominent place in modern art. Thanks to it, the mass movement for "new ways", which developed in the interwar period, was directed to the traditions and realities of the Ukrainian life.

It should be emphasized that the experience of the submitted research is the part of the essence and forms of the representation of the Ukrainian culture in the world, which require further study.

\section{References}

Biletskyi, L. (1922). Z kontsertnoi sali: Vechir Poezii [Concert Hall: Poetry Evening]. Hromadskyi vistnyk, 36, 4 [in Ukrainian]. 
Bobynskyi, V. (1990). Hist iz nochi: poeziia, proza, publitsystyka, literaturna krytyka, pereklady [The guest of the night: poetry, prose, journalism, literary criticism, translations]. Dnipro [in Ukrainian].

Bohema [Bohemia]. (1923). Hromadskyi vistnyk, 3, 6 [in Ukrainian].

Chainyi vechir [Tea Evening]. (1922). Vpered, 33, 4 [in Ukrainian].

Chmelyk. (1923). Maskarad "Bohemy" [Bohemian Masquerade]. Hromadskyi vistnyk, 28, 4 [in Ukrainian].

Doroshenko, V. (1962). Pro pysmennyka, hromadianyna i druha. (Fedir Dudko: 1885-1962) [About the writer, citizen and friend. (Fedir Dudko: 1885-1962)]. In S. Hordynskyi, H. Zhurba, I. Korovytskyi, H. Kostiuk, B. Kravtsiv, V. Lesych, \& M. Shlemkevych (Eds.), Slovo: zbirnyk ukrainskykh pysmennykiv $v$ ekzyli [Word: a collection of Ukrainian writers in exile] (Vol.1, pp.315-317). Obiednannia ukrainskykh pysmennykiv v ekzyli [in Ukrainian].

Kedryn, I. (1923). Vechir Bohdana Lepkoho [Night of Bohdan Lepkyi]. Hromadskyi vistnyk, 48, 5 [in Ukrainian].

Lepkyi, L. (1922). Mykoli Voronomu (z pryvodu 50-litnoho yuvileiu) [In honour of Mykola Voronyi (on the occasion of the $50^{\text {th }}$ anniversary)]. Budiak, 12, 7 [in Ukrainian].

Lysty M. Voronoho do I. Kalynovycha, Warshava [Letters of M. Voronoi to I. Kalinovich, Warsaw]. (1921-1922). (Fund I. Kalynovycha, File 335, Cover 29, s.51). Viddil rukopysiv, Vasyl Stefanyk National Scientific Library of Ukraine in Lviv, Lviv [in Ukrainian].

Lviv. Vechir Molodoho Mystetstva [Lviv. Young Art Evening]. (1921). Shliakhy mystetstva, 2, 146-147 [in Ukrainian].

Malanchyn Vechir u Lvovi [Malanka’s Evening in Lviv]. (1923). Hromadskyi vistnyk, 23, 7 [in Ukrainian].

Malaniuk, Ye. (1923). Retsenziia na kn.: Obidnyi, M. (1923). Neroztsvili ranky: poezii. Lviv [Book Review: M. Obidnyi (1923). Non-flowering mornings: poetry. Lviv]. Veselka, 9-10, 75 [in Ukrainian].

Maskarad "Bohemy" [The Masquerade of "Bohemia"]. (1923). Hromadskyi vistnyk, 29, p. 3 [in Ukrainian].

Muzychno-literaturnyi vechir v chest Bohdana Lepkoho [Musical and literary evening in honor of Bohdan Lepkyi]. (1923). Hromadskyi vistnyk, 42, 3 [in Ukrainian].

$\mathrm{Na}$ zahalne domahannia [On general demand]. (1922). Budiak, 13, 4 [in Ukrainian].

Nashe viruiu [("Our" I believe"]. (1921). Budiak, 1, 1 [in Ukrainian].

Novynky [New items]. (1922). Hromadskyi vistnyk, 35, 5 [in Ukrainian].

Opovistky [Messages]. (1922). Hromadskyi vistnyk, 16, 7 [in Ukrainian].

Ostroverkha, M. (1957). Obnizhkamy na bytyi shliakh [From Bound to the Beaten Path]. Dnipro [in Ukrainian].

Pershyi "Vesnianyi vechir" [The first "Spring Evening"]. (1922). Vpered, 62, 4 [in Ukrainian].

I-yi chainyi vechir Budiaka [First Tea Party of Budyak]. (1921). Vpered, 168, 4 [in Ukrainian].

Polikarpova, Yu. O. (2012). Prezentatsiia yak aktyvnyi metod navchannia [Presentation as an Active Teaching Method]. Culture of Black Sea People, 231, 159-162 [in Ukrainian].

Pozir! [Look!]. (1922). Vpered, 15, 3 [in Ukrainian]. 
Prokopchuk, I. (2010). Rol mystetskykh chasopysiv 1920 - pochatku 1930-kh rokiv u poshyrenni modernistychnykh kontseptsii v Ukraini [The Role of Art Magazines in the 1920s and early 1930s in the Spread of Modernist Concepts in Ukraine]. Visnyk of Lviv national academy of Arts, 21, 17-25 [in Ukrainian].

Salyha, T. (1993). Literaturna hrupa "Mytusa" i druha khvylia ukrainskoho symvolizmu [The Literary Group "Mytusa" and the Second Wave of Ukrainian Symbolism]. In L. Senyk (Ed.), Druhyi Mizhnarodnyi Konhres Ukrainistiv: dopovidi i povidomlennia. Literaturoznavstvo (Lviv, 22-28 serpnia 1993 r.) [Second International Congress of Ukrainians: reports and communications. Literary Studies (Lviv, August 22-28, 1993)] (pp. 168-175). Vidrodzhennia [in Ukrainian].

Salyha, T. Yu. (1997). Imperatyv (literaturoznavchi statti, krytyka, publitsystyka) [Imperative (literary articles, criticism, journalism)]. Svit [in Ukrainian].

Savchyn, Yu. O. (2014). Ukrainsko-polski vidnosyny na storinkakh zhurnalu "Budiak" (1921-1923 roky) - providna tematychna liniia chasopysu [Ukrainian-Polish Relations on the pages of "Budiak" Magazine (1921-1923) is a leading thematic line of the magazine]. State and Regions. Series: Social Communications, 1-2, 41-44 [in Ukrainian].

Shvung. (1921). Po ravti: z tsykliu "Karnavalovi nastroi" [On the Advice: from the Cycle "Carnival Mood"]. Budiak, 2, 5 [in Ukrainian].

Snitsarchuk, L. V. (2001). Ukrainska satyrychno-humorystychna presa Halychyny 20-30-kh rokiv XX stolittia [Ukrainian satirical and humorous press of Galicia of 20-30 years of $20^{\text {th }}$ century]. Vasyl Stefanyk National Scientific Library of Ukraine in Lviv [in Ukrainian].

Snitsarchuk, L. V. (2009). Ukrainska presa Halychyny (1919-1939 roky) $i$ zhurnalistykoznavchyi dyskurs [Galicia's Ukrainian Press (1919-1939) and Journalistic Discourse] [Monograph]. Vasyl Stefanyk National Scientific Library of Ukraine in Lviv.

Spivomovkam [Ditty]. (1921). Budiak, 5-6, 2 [in Ukrainian].

Syrota, L. B. (1998). Literaturna hrupa "Mytusa" i Pavlo Kovzhun [The Literary Group "Mytusa" and Pavlo Kovzhun]. Narodoznavchi Zoshyty, 5, 538-547 [in Ukrainian].

Syrota, L. B. (2004). Literaturna hrupa "Mytusa" (1921-1922): O. Babii, V. Bobynskyi, R. Kupchynskyi, Yu. Shkrumeliak: bibliohrafichnyi pokazhchyk [The Literary Group "Mytusa" (1921-1922): O. Babii, V. Bobynskyi, R. Kupchynskyi, Yu. Shkrumeliak: bibliographic index]. Vasyl Stefanyk National Scientific Library of Ukraine in Lviv [in Ukrainian].

Syrota, L. B. (2005). Zakhidnoukrainskyi literaturnyi futuryzm pochatku 1920-kh rokiv (za materialamy zhurnalu "Budiak" (1921-1923 roky) [Western Ukrainian Literary Futurism of the Early 1920s (Based on "Budiak" Magazine (1921-1923)]. Zbirnyk prats Naukovo-doslidnoho tsentru periodyky, 13, 221-242) [in Ukrainian].

Tarnohradskyi, V. (1921). Klym Polishchuk. Budiak, 13, 3 [in Ukrainian].

Tarnopolskyi, O. B. \& Avsiukevych, Yu. S. (2007). Uspishni prezentatsii [Successful Presentations]. Lenvit [in Ukrainian].

Tost [Toast]. (1921). Budiak, 1, 8 [in Ukrainian].

V. P. (1921). Z literaturnoho zhyttia na emihratsii [From literary life to emigration]. Ukrainska trybuna, 170, 3 [in Ukrainian].

Vechir "plachu" ["Crying" night]. (1922). Vpered, 55, 4 [in Ukrainian]. 
Vechir plachu Budiaka [Crying night of "Budiak"]. (1922). Vpered, 56, 4 [in Ukrainian]. Vechir, posviachenyi tvorchosti Bohdana Lepkoho [A night dedicated to the creative work of Bohdan Lepkyi]. (1923). Hromadskyi vistnyk, 15, 7 [in Ukrainian].

Velykyi Po-Malanchyn Vechir Smikhu [Big Malanka Night of Laughter]. (1922). Vpered, 3, p. 4 [in Ukrainian].

Vesnianyi "vechir plachu" [Spring "crying night"]. (1922). Vpered, 58,3 [in Ukrainian]. Voronyi, M. (1922). "Mytusa" ["Mytusa"]. Ukrainska trybuna, 43, 2-3 [in Ukrainian]. Yefremov, S. (1995). Istoriia ukrainskoho pysmenstva [History of the Ukrainian Writing]. Femina [in Ukrainian].

Zhontik. (1923). Khronika [Chronicle]. Hromadskyi vistnyk, 18, 3 [in Ukrainian]. Zi studentskoho zhyttia [From student life]. (1921). Postup, 12, 308 [in Ukrainian]. Zi studentskoho zhyttia. Halychyna. Vechir Molodoho Mystetstva [From student life. Galicia. Young Art Evening]. (1922). Postup, 1-2, 52-53 [in Ukrainian].

\section{ПРЕЗЕНТАЦІЙНА ДІЯЛЬНІСТЬ ЛІТЕРАТУРНИХ І МИСТЕЦЬКИХ ОБ'ЄДНАНЬ ЛЬВОВА ПОЧАТКУ 1920-х РОКІВ}

\section{Сирота Лілія Богданівна}

Кандидат філологічних наук, доцент, ORCID:0000-0001-7237-291X, liljasyrota@yahoo.com, Львівський національний університет імені Івана Франка, Львів, Україна

Метою статті є розкриття особливостей презентаційної діяльності українських осередків Львова початку 1920-х рр., поглиблення знань про українське культурне життя цього міста. Для аналізу залучено матеріали періодичних видань того часу. Методологія дослідження. Визначальним методологічним принципом у дослідженні став принцип історизму, який дозволив визначити значення, місце і наслідки презентаційної діяльності як нової форми спілкування творчих об’єднань. Системний підхід дав можливість визначити взаємодію творчих груп Галичини 1920-х рр., а методи аналізу та синтезу використовувалися для дослідження створення умов для ефективної комунікації з аудиторією з метою відновлення культурного життя. Наукова новизна полягає в тому, що комплексно досліджено конкретні літературно-мистецькі події та їх значення для успішної творчої діяльності. Презентаційна активність стала можливою завдяки постійному попиту на творчі інновації, який регулярно зростав у Галичині з часів національно-визвольних змагань.

Висновки. Встановлено, що презентаційна діяльність у 1920-х рр. стала новою та сенсаційною на той час формою спілкування з прихильниками творчих об'єднань та була спрямована на піднесення культурного життя Галичини. При цьому презентації найбільш відповідали суспільно-культурним вимогам та приносили величезний успіх їх організаторам тому, що про них були написані розширені відгуки у пресі, а також завдяки умінню митусівців сконцентрувати навколо себе не тільки українські літературні сили Галичини, а й еміграції, що формувалася в Польщі, Чехо-Словаччині, 
Німеччині, Австрії у 1920-ті рр. Доведено, що ініціатори мистецьких заходів - групи «Митуса» і «Богема», автори журналу «Будяк» зуміли встановити зв’язки шляхом залучення інших на свою сторону, прищеплення їм своїх думок і форм поведінки та запропонувати в загальне користування авангардистську ідеологію і світогляд через нав’язування прихильникам бажаних ідей і форм поведінки під час творчих вечорів та через власну послідовність цим ідеям. Таким чином, творча презентація посідає чільне місце у модерному мистецтві. Завдяки їй масовий рух за «нові шляхи», що розгорнувся у міжвоєнний період, був спрямований до традицій і реалій українського життя.

Ключові слова: презентація; 1920-ті рр.; Галичина; Львів; творчі пошуки; літературна група «Митуса»; журнал «Будяк»; літературно-мистецьке товариство «Богема»; ідея; світогляд; суспільно-культурні вимоги.

\section{ПРЕЗЕНТАЦИОННАЯ ДЕЯТЕЛЬНОСТЬ ЛИТЕРАТУРНЫХ И ХУДОЖЕСТВЕННЫХ ОБЪЕДИНЕНИЙ ЛЬВОВА НАЧАЛА 1920-х ГОДОВ}

\section{Сирота Лилия Богдановна}

Кандидат филологических наук, доцент, ORCID: 0000-0001-7237-291X, liljasyrota@yahoo.com, Львовский национальный университет имени Ивана Франко, Львов, Украина

Целью статьи является раскрытие особенностей презентационной деятельности украинских организаций Львова начала 1920-х гг., углубление знаний об украинской культурной жизни этого города. Для анализа привлечены материалы периодических изданий того времени. Методология исследования. Определяющим методологическим принципом в исследовании стал принцип историзма, который позволил определить значение, место и последствия презентационной деятельности как новой формы общения творческих объединений. Системный подход позволил определить взаимодействие творческих групп Галичины 1920-х гг., а методы анализа и синтеза использовались для исследования создания условий для эффективной коммуникации с аудиторией с целью восстановления культурной жизни. Научная новизна заключается в том, что комплексно исследованы конкретные литературно-художественные события и их значение для успешной творческой деятельности. Презентационная активность стала возможной благодаря постоянному спросу на творческие инновации, который регулярно рос в Галиции со времен национально-освободительной борьбы.

Выводы. Установлено, что презентационная деятельность в 1920-х гг. стала новой и сенсационной в то время формой общения со сторонниками творческих объединений и была направлена на подъем культурной жизни Галичины. При этом презентации наиболее соответствовали общественно-культурным требованиям и приносили огромный успех их организаторам, поскольку о них были написаны расширенные отзывы в прессе, а также благодаря умению митусовцев сконцентрировать вокруг себя не только украинские литературные силы Галичины, но и эмиграцию, которая 
формировалась в Польше, Чехо-Словакии, Германии, Австрии в 1920-е гг. Доказано, что инициаторы культурных мероприятий - группы «Митуса» и «Богема», авторы журнала «Чертополох» сумели установить связи путем привлечения других на свою сторону, привития им своих мыслей и форм поведения и предложить в общее пользование авангардистскую идеологию и мировоззрение через навязывание сторонникам желаемых идей и форм поведения во время творческих вечеров и через собственную последовательность этим идеям. Таким образом, творческая презентация занимает видное место в модерном искусстве. Благодаря ей массовое движение за «новые пути», развернувшееся в межвоенный период, было направлено к традициям и реалиям украинской жизни.

Ключевые слова: презентация; 1920-е гг.; Галичина; Львов; творческие поиски; литературная группа «Митуса»; журнал «Чертополох»; литературно-художественное общество «Богема»; идея; мировоззрение; общественно-культурные требования. 